\title{
PENGARUH MODEL PEMBELAJARAN NHT TERHADAP HASIL BELAJAR GEOMETRI DITINJAU DARI KEMAMPUAN SPASIAL SISWA SD
}

\author{
I Wayan Parwata \\ ${ }^{123}$ Program Studi Pendidikan Dasar, Universitas Pendidikan Ganesha, Singaraja \\ e-mail: wayan.parwata@pasca.undiksha.ac.id
}

\begin{abstract}
Abstrak
Tujuan penelitian adalah untuk mengetahui pengaruh implementasi model pembelajaran Numbered Heads Together (NHT) terhadap hasil belajar geometri ditinjau dari kemampuan spasial siswa kelas V SD di Gugus Ngurah Rai Kecamatan Denpasar Barat. Data dianalisis menggunakan ANAKOVA dengan bantuan SPSS 17.0 for windows. Sebanyak 82 siswa kelas $V$ dipilih sebagai sampel dengan teknik random sampling. Data yang dikumpulkan adalah data hasil belajar dan kemampuan spasial siswa dengan tes pilihan ganda.

Hasil penelitian menunjukan bahwa: pertama, terdapat perbedaan yang signifikan hasil belajar geometri antara siswa yang mengikuti model pembelajaran NHT dan siswa yang mengikuti model pembelajaran konvensional ( Fhitung $=9,119>$ Ftabel $=4,00$ ). Kedua, setelah dikendalikan oleh kovariabel kemampuan spasial, terdapat perbedaan yang signifikan antara hasil belajar geometri siswa yang mengikuti model pembelajaran $\mathrm{NHT}$ dan siswa yang mengikuti model pembelajaran konvensional (Fhitung $=12,182>$ Ftabel $=4,00$ ). Ketiga, terdapat kontribusi kovariabel kemampuan spasial yang signifikan terhadap hasil belajar geometri siswa (rhitung $=0,551>$ rtabel $=0,215$ ).
\end{abstract}

Kata Kunci: NHT, hasil belajar, kemampuan spasial, matematika

\begin{abstract}
The purpose of this study is to investigate the effect of implementation of Numbered Heads Together (NHT) learning model on geometry Learning result viewed from spatial ability of fifth grade students in cluster Ngurah Rai sub-district Denpasar Barat. Data were analyzed using ANAKOVA with the help of SPSS 17.0 for windows. About 82 fifth grade students were selected as sample by using random sampling technique. Data collected were data of learning result and students's spatial learning using multiple choice. The result shows that first, there's a significant difference in geometry result between students who followed NHT learning model and students who followed conventional learning model ( Fhitung $=9,119>$ Ftabel $=4,00$ ). Second, after controlled by spatial ability covariable, there's a significant difference between geometry result in students who followed NHT learning model and students who followed conventional learning model (Fhitung $=12,182>$ Ftabel $=4,00$ ). Third, there's a significant contribution of spatial ability covariable to student's geometry result (rhitung $=0,551>$ rtabel $=0,215$ ).
\end{abstract}

Keyword: NHT, learing result, spatial ability, mathematic 


\section{Pendahuluan}

Pendidikan di Indonesia merupakan hal yang perlu mendapat perhatian serius dan bersungguh-sungguh. Berdasarkan data dalam Education for All (EFA) Global Monitroring Report 2011 yang dikeluarkan UNESCO dan diluncurkan di New York pada Senin, 1/3/2011, indeks pembangunan pendidikan Indonesia berada pada urutan 69 dari 127 negara yang disurvei. Tahun lalu dengan ukuran yang sama, peringkat Indonesia berada pada urutan 65 . Tentu saja peringkat ini sangat jauh di bandingkan dengan negara-negara tetangga kita. (Kompas, 2011).

Untuk meningkatkan mutu pendidikan tersebut menjadi tanggung jawab sekolah walaupun tidak sepenuhnya karena pendidikan tidak hanya didapatkan di sekolah. Namun pihak sekolah tidak boleh berpangku tangan dan tetap menjadi pionir dalam meningkatkan mutu pendidikan tersebut. Salah satu caranya adalah melalui perbaikan pada proses belajar serta membiasakan siswa berpikir kritis.

Berpikir kritis salah satunya dapat dikembangkan dengan belajar matematika karena struktur dan keterkaitan yang kuat dan jelas antar konsep matematika. Depdiknas (2004) memaparkan fungsi matematika di sekolah adalah sebagai salah satu unsur masukan instrumental, yang memiliki obyek dasar abstrak dan berlandaskan kebenaran konsistensi, dalam sistem proses belajar mengajar untuk mencapai tujuan sekolah.

Menurut Depdikbub (dalam Suarjana, 2001:3) tujuan diberikannya matematika pada jenjang pendidikan dasar dibagi menjadi dua bagian, yaitu tujuan umum dan tujuan khusus. Adapun yang menjadi tujuan umum pengajaran matematika pada jenjang pendidikan dasar adalah sebagai berikut, (1) mempersiapkan siswa agar sanggup menghadapi perubahan keadaan di dalam kehidupan dan dunia nyata yang selalu berkembang, melalui latihan bertindak atas dasar pemikiran secara logis, rasional, kritis, cermat, jujur, dan efektif, (2) mempersiapkan siswa agar dapat menggunakan matematika dan pola pikir matematika dalam kehidupan sehari-hari dan dalam mempelajari berbagai ilmu pengetahuan. Tujuan umum program matematika ini menekankan pada penataan nalar siswa, pembentukan sikap dan keterampilan siswa untuk menerapkan matematika. Sedangkan tujuan khusus dari pengajaran matematika pada jenjang pendidikan dasar adalah sebagai berikut (1) menumbuhkan dan mengembangkan keterampilan berhitung sebagai alat dalam kehidupan sehari-hari, (2) menumbuhkan kemampuan siswa yang dapat dialihgunakan melalui kegiatan matematika, (3) mengembangkan pengetahuan dasar matematika sebagai bekal belajar lebih lanjut di SLTP, dan (4) membentuk sikap logis, kritis, cermat, kreatif dan disiplin.

Dengan mempelajari matematika, siswa mampu mengembangkan kemampuan menghitung, mengukur dan menggunakan rumus matematika yang diperlukan dalam kehidupan sehari-hari melalui konsep-konsep matematika misalnya aljabar dan trigonometri, serta materi pengukuran dan geometri. Mempelajari geometri penting karena geometri telah menjadi alat utama untuk mengajar seni berpikir (Wikipedia, 2012). Melihat pentingnya Geometri, tidak heran seorang matematikawan kuno (Thales) pernah mengatakan bahwa "Tuhan menciptakan umatnya berdasarkan Geometri" (Hasan, 2011), dan apabila ditinjau dari sudut pandang psikologi juga memuat tentang kemampuan ganda yang hendaknya dikuasai siswa. Teori mengenai kemampuan ganda dikemukakan oleh Horward Gardner (dalam Riyanto, 2010: 236) melalui bukunya berjudul Frames of Mind: the Theory of Multiple Intelligence pada tahun 1983, yang menyatakan bahwa kecerdasan orisinal (bakat) setiap individu itu berbeda-beda, yang dikelompokkan ke dalam jenis kecerdasan: linguistik, logismatematis, musikal, kinestetik tubuh, interpersonal, intrapersonal, naturalis, eksistensi, dan kemampuan spasial,

Kemampuan spasial yang merupakan salah satu dari kemampuan ganda, memiliki konsep abstrak yang meliputi persepsi spasial yang melibatkan hubungan spasial (kemampuan untuk mengamati hubungan posisi objek dalam ruang), kerangka acuan (tanda yang dipakai sebagai patokan untuk menentukan posisi objek dalam ruang), hubungan proyektif (kemampuan untuk melihat objek dari berbagai sudut pandang), konservasi jarak (kemampuan untuk memperkirakan jarak antara dua titik), representasi spasial (kemampuan untuk 
merepresentasikan hubungan spasial dengan memanipulasi secara kognitif), rotasi mental (membayangkan perputaran objek dalam ruang), termasuk orientasi sampai pada kemampuan yang rumit yang melibatkan manipulasi serta rotasi mental (Tambunan, 2006).

Beberapa penelitian yang dilakukan oleh para peneliti terkait dengan kemampuan spasial menunjukkan bahwa terdapat hubungan kemampuan spasial terhadap hasil belajar matematika. Kemampuan spasial dengan konsep matematika taraf tinggi terdapat hubungan yang positif. Penelitian tersebut dilaksanankan oleh Smith (1980). Begitu pula dengan penelitian dari Sherman (1980) terhadap anak usia sekolah, menemukan adanya hubungan yang positif antara prestasi belajar matematika dan kemampuan spasial. Hal ini menunjukkan bahwa kemampuan spasial merupakan tuntutan kurikulum yang harus diakomodasi dalam pembelajaran di kelas. Kemampuan spasial ini diperlukan dalam belajar matematika khususnya geometri. Penggunaan kemampuan spasial seperti membuat bagan, bentuk-bentuk geometri dapat membantu anak menguasai matematika.

Dengan menyadari hal tersebut, guru sebaiknya mulai memikirkan strategi atau model pembelajaran yang tepat untuk mengembangkan kemampuan-kemampuan tersebut. Model pembelajaran yang diterapkan harus memberikan kesempatan kepada siswa untuk mengkonstruksi pengetahuannya sendiri sehingga siswa lebih mudah untuk memahami konsep-konsep dalam sebuah kelompok belajar atau kooperaktif. Kooperaktif mengandung pengertian bekerja bersama dalam mencapai tujuan secara bersama-sama yang sifatnya merata dan menguntungkan setiap anggota kelompoknya (Ade, 2009). Membudayakan belajar kelompok pada siswa bisa dilakukan dengan menggunakan berbagai model-model pembelajaran yang relevan untuk diterapkan, termasuk pembelajaran kooperaktif.

Salah satu model pembelajaran kooperaktif adalah Numbered Head Together (NHT). Model pembelajaran NHT merupakan cara belajar kooperaktif atau beberapa kelompok, dimana siswa dikelompokan menjadi beberapa kelompok. Setiap siswa dalam setiap kelompok mendapat nomor, guru memberi tugas kepada setiap siswa berdasarkan nomor, jadi setiap siswa memiliki tugas berbeda.

Model pembelajaran NHT merupakan jenis pembelajaran kooperatif yang dirancang untuk mempengaruhi pola interaksi siswa dan sebagai alternatif struktur kelas tradisional (Trianto, 2009;82). Model pembelajaran NHT juga merupakan suatu cara penyajian pelajaran dengan melakukan percobaan, mengalami dan membuktikan sendiri sesuatu permasalahan yang dipelajari. Dengan model pembelajaran NHT siswa diberi kesempatan untuk mengalami sendiri atau melakukan sendiri, mengikuti suatu proses, mengamati suatu objek, menganalis, membuktikan dan menarik kesimpulan sendiri tentang suatu objek dan keadaan suatu proses pembelajaran mata pelajaran tertentu.

Berdasarkan uraian di atas, merupakan hal yang penting untuk meneliti pengaruh model pembelajaran NHT terhadap hasil belajar geometri siswa. Demikian pula dengan memperhatikan kemampuan spasial yang dimiliki siswa. Dalam konteks inilah peneliti melakukan penelitian yang berjudul "Pengaruh implementasi model pembelajaran NHT terhadap hasil belajar geometri ditinjau dari kemampuan spasial siswa kelas $\mathrm{V}$ sekolah dasar di Gugus Ngurah Rai Kecamatan Denpasar Barat".

\section{Metode}

Jenis penelitian ini adalah penelitian eksperimen semu dengan rancangan posttest-only control-group desain. Variabel-variabel dalam penelitian ini adalah (1) variabel bebas dalam penelitian ini adalah pembelajaran model pembelajaran kooperatif tipe NHT dan pembelajaran konvensional, (2) variabel terikat dalam penelitian ini adalah hasil belajar siswa, dan (3) yang menjadi kovaribel dalam penelitian ini adalah kemampuan spasial.

Populasi penelitian ini adalah seluruh kelas V SD di gugus Ngurah Rai Kecamatan Denpasar Barat. Berdasarkan uji kesetaraan, sampel penelitian ini adalah kelas VB SD No. 3 Padangsambian dan kelas VA SD No.18 Padangsambian dengan jumlah keseluruhan 82 orang siswa. Data yang dikumpulkan dalam penelitian ini adalah data hasil belajar geometri dan 
kemampuan spasial siswa dengan tes pilihan ganda dan dianalisis menggunakan ANAKOVA dengan bantuan SPSS 17.0 for windows.

Untuk menentukan validitas isi tes pilihan ganda dan tes kemampuan spasial dilakukan penilaian oleh para pakar. Setelah dianalisis, didapatkan koefisien validitas isi tes hasil belajar geometri adalah 1, dan koefisien validitas isi tes kemampuan spasial adalah 0,975. Untuk mengetahui validitas dan reliabilitas instrumen yang akan digunakan dalam penelitian dilakukan uji coba instrument. Hasil analisis instrument hasil belajar geometri diperoleh validitas sebesar rxy $=0,82>$ rtabel $=0,25$, dan reliabilitas sebesar $r x y=0,90>$ rtabel $=0,25$. Sedangkan hasil analisis instrument kemampuan spasial diperoleh validitas sebesar rxy $=0,76>$ rtabel $=0,304$, dan reliabilitas sebesar $r x y=0,86>$ rtabel $=0,304$. Dengan demikian dapat disimpulkan instrumen yang digunakan dalam penelitian ini telah valid dan reliabel.

Data dalam penelitian dianalisis secara bertahap, yaitu: deskripsi data, uji prasyarat, dan uji hipotesis. Pendeskripsian data hasil belajar geometri dan kemampuan spasial siswa berdasarkan tendensi data, meliputi mean, median, modus, standar deviasi, varians, rentangan, skor maksimum, dan skor minimum. Selanjutnya dilakukan perhitungan sentral dari masing-masing data untuk mencari mean, median, modus, serta standar deviasi dari tiap-tiap kelompok data tersebut. Uji prasyarat yang dilakukan adalah uji normalitas sebaran data, uji homogenitas varians, serta uji linearitas dan keberartian arah regresi. Pengujian normalitas dilakukan untuk meyakinkan bahwa sampel berasal dari populasi yang berdistribusi normal, sehingga uji hipotesis dapat dilakukan. Uji normalitas data dilakukan pada empat kelompok data. Kelompok pertama adalah hasil belajar geometri siswa yang mengikuti pembelajaran dengan model pembelajaran NHT pada mata pelajaran matematika kelompok kedua adalah kemampuan spasial siswa yang mengikuti pembelajaran dengan model pembelajaran NHT, kelompok ketiga data hasil belajar geometri siswa pada pelajaran matematika yang mengikuti pembelajaran dengan model pembelajaran konvensional, dan kelompok keempat data kemampuan spasial siswa yang mengikuti pembelajaran dengan model pembelajaran konvensional. UJi normalitas pada keempat kelompok data menggunakan SPSS-PC 17 for Windows uji statistik Kolmonogov-smirnov pada signifikansi 0,05.

Uji homogenitas varians antar kelompok digunakan untuk meyakinkan bahwa perbedaan yang terjadi pada uji hipotesis benar-benar berasal dari perbedaan antara kelompok, bukan terjadi akibat dari perbedaan yang terjadi di dalam kelompok (Candiasa, 2010). Uji homogenitas varians antara kelompok juga dimaksudkan untuk memperlihatkan bahwa dua atau lebih kelompok data sampel berasal dari populasi yang memiliki varians yang sama. Uji homogenitas varians antar kelompok menggunakan Levene's test of Equality of Error Variance (Candiasa, 2010). Uji ini dapat dilakukan dengan memanfaatkan bantuan SPSS-PC 17 for Windows. Kriteria pengujian: data memiliki varians yang sama (homogen) jika angka signifikansi yang diperoleh lebih besar dari 0,05 dan dalam hal lain varians sampel tidak sama (tidak homogen).

Uji Linearitas dimaksudkan untuk mengetahui hubungan antara varibel bebas dengan variabel terikat. Selain itu, uji linearitas juga diharapkan dapat mengukur taraf signifikansi penyimpangan dari linearitas hubungan tersebut. Apabila penyimpangan yang ditemukan tidak signifikan, maka hubungan antara variabel bebas dan varibel terikat adalah linear. Uji ini dapat dilakukan dengan memanfaatkan bantuan SPSS-PC 17 for Windows pada taraf signifikansi 5\% dengan kriteria pengujian sebagai berikut. Untuk pengujian kelinearan garis regresi nilai Fhitung dibandingkan dengan Ftabel. Bila Fhitung < Ftabel maka garis regresi berarti (signifikan). Untuk pengujian keberartian garis regresi nilai Fhitung (regresi) dibandingkan dengan Ftabel. Bila Fhitung > Ftabel maka garis regresi berarti (signifikan). Hipotesis yang diuji dalam penelitian ini, meliputi: (1) terdapat perbedaan hasil belajar geometri antara siswa yang mengikuti model pembelajaran NHT dengan siswa yang mengikuti model pembelajaran konvensional. Analisis yang digunakan adalah analisis varian satu jalur dengan kriteria pengujian: jika pada taraf signifikansi 5\%, maka terdapat perbedaan hasil belajar geometri antara siswa yang mengkuti model pembelajaran NHT dengan siswa yang mengikuti model pembelajaran konvensional. (2) Setelah kovariabel kemampuan spasial dikendalikan, terdapat perbedaan hasil belajar geometri antara siswa yang mengkuti model pembelajaran 
NHT dengan siswa yang mengikuti model pembelajaran konvensional. Analisis yang digunakan adalah ANAKOVA dengan kovariabel kemampuan spasial. Kriteria pengujian: jika pada taraf signifikansi 5\%, maka setelah kovariabel kemampuan spasial dikendalikan, terdapat perbedaan hasil belajar geometri antara siswa yang mengkuti model pembelajaran NHT dengan siswa yang mengikuti model pembelajaran konvensional. (3) Terdapat kontribusi kovariabel kemampuan spasial terhadap hasil belajar geometri siswa. Analisis yang digunakan adalah korelasi product moment dengan kriteria jika pada taraf signifikansi 5\%, maka kemampuan spasial memiliki kontribusi terhadap hasil belajar geometri siswa. Sementara itu, jika untuk mengetahui berapa besar kontribusi kovaribel kemampuan spasial terhadap hasil belajar geometri, nilai koefisien korelasi product moment (rxy) dikuadratkan. Sehingga, nilai kontribusi kovaribel kemampuan spasial terhadap hasil belajar geometri adalah r2xy.

\section{Hasil dan Pembahasan}

Hasil analisis deskriptif data penelitian dapat dilihat pada tabel 1 di bawah ini.

Tabel 1. Rekapitulasi Hasil Perhitungan Skor Hasil Belajar dan Kemampuan Spasial

\begin{tabular}{ccccc}
\hline Variabel Statistik & X1 & Y1 & X2 & Y2 \\
\hline Mean & 65,7 & 57,2 & 52,9 & 55,4 \\
Median & 62,5 & 56,7 & 52,5 & 53,3 \\
Modus & 57,5 & 63,3 & 52,5 & 50 \\
Standar Deviasi & 13,1 & 17,8 & 10 & 16,9 \\
Varians & 172,8 & 317,5 & 100,7 & 287,6 \\
Rentang & 50,0 & 66,7 & 40,0 & 66,7 \\
Skor Minimum & 42,5 & 23,3 & 35,0 & 23,3 \\
Skor Maksimum & 92,5 & 90,0 & 75,0 & 90,0 \\
\hline
\end{tabular}


Keterangan:

$\mathrm{X} 1=$ hasil belajar geometri siswa yang mengikuti pembelajaran dengan model pembelajaran NHT.

Y1 = kemampuan spasial siswa yang mengikuti pembelajaran dengan model pembelajaran NHT.

$\mathrm{X} 2$ = hasil belajar geometri siswa yang mengikuti pembelajaran dengan model pembelajaran konvensional.

Y2 = kemampuan spasial siswa yang mengikuti pembelajaran dengan model pembelajaran konvensional.

Hasil analisis deskriptif tentang hasil belajar geometri siswa yang mengikuti pembelajaran dengan model pembelajaran NHT menunjukkan bahwa rata-rata skor hasil belajar siswa yang mengikuti pembelajaran dengan model pembelajaran NHT adalah 65,7 lebih besar dari rata-rata hasil belajar siswa yang mengikuti pembelajaran dengan model pembelajaran konvensional yaitu sebesar 52,9. Begitupula dengan rata-rata skor kemampuan spasial siswa yang mengikuti pembelajaran dengan model pembelajaran NHT yaitu sebesar 57,2 lebih besar dari rata-rata kemampuan spasial siswa yang mengikuti pembelajaran dengan model pembelajaran konvensional yaitu sebesar 55,4. Oleh karena itu dapat disimpulkan bahwa hasil belajar geometri siswa yang mengikuti pembelajaran dengan model pembelajaran NHT lebih tinggi daripada hasil belajar geometri siswa yang mengikuti pembelajaran dengan model pembelajaran Konvensional.

Hasil uji normalitas sebaran data menunjukkan bahwa nilai-nilai signifikansi data pada Kolmonogov-Smirnov memiliki angka lebih besar dari 0,05 yaitu $\mathrm{X} 1=0,070, \mathrm{Y} 1=0$, $200, X 2=0,200, Y 2=0,200$. Dengan demikian maka semua sebaran data berdistribusi normal. Hasil uji homogenitas varian antar kelompok menunjukkan angka signifikansi X1X2 dan Y1Y2 masing-masing adalah 0,384 dan 0,280 lebih besar dari 0,05. Dengan demikian, semua kelompok memiliki varians yang homogen.

Berdasarkan hasil uji linearitas regresi hasil belajar geometri dan kemampuan spasial siswa yang mengikuti pembelajaran dengan model pembelajaran NHT diketahui bahwa nilai signifikansi dari Deviation from Linearity adalah 0,981 yaitu lebih besar dari pada 0,05. Dengan demikian, dapat disimpulkan bahwa bentuk regresi dari data hasil belajar geometri dan kemampuan spasial siswa yang mengikuti pembelajaran dengan model pembelajaran NHT memang benar linier. Sedangkan pengujian keberartian arah regresi dilakukan dengan memperhatikan Linearity. Berdasarkan tabel di atas, nilai signifikansi Linearity sebesar 0,000 dan lebih kecil dari pada 0,05. Dengan demikian koefisien arah regresi berarti atau signifikan. Hasil uji linearitas regresi hasil belajar geometri dan kemampuan spasial siswa yang mengikuti pembelajaran dengan model konvensional diketahui bahwa nilai signifikansi dari Deviation from Linearity adalah 0,973 yaitu lebih besar dari pada 0,05 . Dengan demikian, dapat disimpulkan bahwa bentuk regresi dari data hasil belajar geometri dan kemampuan spasial siswa yang mengikuti pembelajaran dengan model konvensional memang benar linier. Sedangkan pengujian keberartian arah regresi dilakukan dengan memperhatikan Linarity. Berdasarkan tabel di atas, nilai signifikansi Linearity sebesar 0,030 dan lebih kecil dari pada 0,05. Dengan demikian koefisien arah regresi berarti atau signifikan. Hasil uji hipotesis pertama dapat dilihat pada tabel 2 di bawah ini.

Tabel 2. Hasil Uji Hipotesis Data Hasil Belajar Geometri Siswa

\section{ANOVA}

\begin{tabular}{lccccc}
\hline & Sum of Squares & Df & Mean Square & $F$ & Sig. \\
\hline Between Groups & 2477.229 & 2 & 1238.615 & 9.119 & .000 \\
Within Groups & 10730.393 & 79 & 135.828 & &
\end{tabular}




\section{ANOVA}

\begin{tabular}{lccccc}
\hline & Sum of Squares & Df & Mean Square & $F$ & Sig. \\
\hline Between Groups & 2477.229 & 2 & 1238.615 & 9.119 & .000 \\
Within Groups & 10730.393 & 79 & 135.828 & & \\
Total & 13207.622 & 81 & & & \\
\hline
\end{tabular}

Berdasarkan hasil analisis data hasil belajar geometri siswa yang mengikuti pembelajaran dengan model pembelajaran $\mathrm{NHT}$ dan model konvensional diperoleh harga $F_{\text {hitung }}$ sebesar 9,119 $>F_{\text {tabel }}=4,00$ dan angka signifikansi 0,000 lebih kecil dari 0,05. Dengan demikian hipotesis nol $(\mathrm{H} 0)$ ditolak, dan hipotesis alternative $(\mathrm{H} 1)$ yang menyatakan bahwa "terdapat perbedaan hasil belajar geometri antara siswa yang mengikuti model pembelajaran $\mathrm{NHT}$ dengan siswa yang mengikuti model pembelajaran konvensional", diterima.

Hasil uji hipotesis pertama dalam penelitian ini telah terbukti bahwa hasil belajar geometri siswa yang mengikuti pembelajaran dengan model pembelajaran NHT lebih baik daripada hasil belajar geometri siswa yang mengikuti pembelajaran dengan model pembelajaran Konvensional. Hal ini disebabkan karena perbedaan cara atau langkah dalam penerapan model pembelajaran NHT dan model pembelajaran konvensional. Pada model pembelajaran konvensional proses belajar mengajar lebih sering diarahkan pada "aliran informasi" atau "transfer" pengetahuan dari guru ke siswa, sehingga dalam proses pembelajaran di kelas guru menjadi aktif, tetapi siswa pasif dan pembelajaran berpusat pada guru. Dalam model pembelajaran konvensional, pola pembelajaran atau urutan sajian materi khususnya dalam pembelajaran matematika adalah (1) guru mengawali dengan memberikan siswa penjelasan tentang suatu teori, defenisi, teorema yang harus dihafal, (2) memberikan contoh soal dan (3) diakhiri dengan latihan soal. Ketika latihan soal, siswa diberi kesempatan untuk melakukan pelatihan dan pemberian umpan balik terhadap keberhasilan siswa. Pada fase ini pula, guru jarang memberikan kesempatan kepada siswa untuk menerapkan pengetahuan dan keterampilannya yang dipelajarinya ke dalam situasi kehidupan nyata. Dalam model pembelajaran konvensional, metode ceramah merupakan pilihan utama sebagai metode pembelajaran.

Berbeda dengan model pembelajaran NHT yang melibatkan para siswa dalam proses pembelajaran. Ketika diterapkannya model pembelajaran NHT, guru maupun siswa menjadi lebih aktif. Langkah-langkah pembelajaran yang diterapkan pada model pembelajaran NHT lebih berpusat pada siswa. Langkah-langkah tersebut antara lain: (1) Membagi siswa menjadi beberapa kelompok dan memberikan nomor kepada mereka. Dengan demikian secara tidak langsung guru memberikannya tanggung jawab kepada masing-masing siswa. Hal ini sejalan dengan prinsip hasil belajar, yakni hasil belajar harus memungkinkan terjadinya perubahan perilaku indvidu. Perubahan itu harus merupakan buah dari pengalaman, dan bahwa perubahan itu terjadi pada perilaku indvidu yang mungkin. Dalam kegiatan ini guru melatih siswa untuk mmemupuk rasa tanggung jawab. Dalam kelompok setiap siswa berpikir bersama, dan melatihkan proses inkuiri keterampilan proses pembelajarannya untuk menggambarkan tiap siswa mampu menemukan, melaksanakan, dan menjawab permasalahan yang ada dalam LKS atau masalah yang diberikan oleh guru. (2) Memberikan kesempatan kepada siswa untuk melakukan diskusi bersama kelompok dalam memecahkan suatu persoalan. Dalam kegiatan ini akan terjalin sebuah kerjasama antara siswa yang pintar dan yang lemah dalam pelajaran. Sehingga siswa yang lebih pintar akan mengajarkan atau ikut membimbing siswa yang lemah. Hal ini akan berpengaruh terjadinya kesetaraan hasil belajar dalam suatu pembelajaran. (3) Melaksanakan pembahasan dengan memanggil nomor siswa. Tujuan dari kegiatan ini adalah mengecek sejauh mana pemahaman siswa terhadap suatu materi pelajaran. Siswa yang dipanggil nomornya berhak menyampaikan hasil pembahasan kelompoknya sesuai kemampuannya. Guru juga dapat mengkolaborasikan model pembelajaran NHT dengan bermain kuis agar 
pembelajaran tidak membosankan bagi sisw, melainkan menyenangkan. Karena apabila siswa sudah merasa senang, materi pelajaran akanmudah diterima dan berpengaruh terhadap hasil belajar siswa.

Di samping itu model pembelajaran NHT juga memberikan manfaat terhadap siswa, antara lain (1) rasa harga diri menjadi lebih tinggi. Hal ini disebabkan oleh merasa dihargainya diri mereka dalam sebuah kelompok dan juga ikut berperan dalam kesuksesan kelompok. (2) Memperbaiki kehadiran. Merasa bahwa dirinya juga akan berperan dalam kelompok, siswa akan lebih aktif dan tidak ingin melewatkan pembelajaran. dengan demikian, rasa tanggung jawab akan terpupuk pulai sejak dini. (3) Penerimaan terhadap indvidu menjadi lebih besar. Walaupun ada salah satu teman yang lemah dalam pembelajaran di dalam kelompoknya, teman yang lain merasa bertanggung jawab mengajari temannya tersebut. (4) Perilaku mengganggu menjadi lebih kecil dan konflik antara pribadi berkurang. Dengan dibentuknya kelompok dan memberikan mereka tugas untuk didiskusikan, maka siswa yang jail akan menahan diri untuk tidak menggangu teman yang lain. (5) Disamping memperoleh pemahaman yang lebih mendalam, dan hasil belajar lebih tinggi, model pembelajaran NHT juga mampu meningkatkan kebaikan budi, kepekaan dan toleransi. Dengan demikian, terbukti bahwa model pembelajaran NHT lebih baik dengan model pembelajaran konvensional. Sehingga jelas terlihat perbedaan antara hasil belajar geometri siswa yang mengikuti pembelajaran dengan model pembelajaran NHT dibandingkan dengan hasil belajar geometri siswa yang mengikuti pembelajaran dengan model pembelajaran konvensional.

Temuan dalam penelitian ini sesuai dengan hasil penelitian yang dilaksanakan oleh Supena (2010) yang berjudul Pengaruh Model Pembelajaran Kooperatif Numbered Head Together terhadap hasil belajar matematika ditinjau dari motivasi belajar peserta didik kelas VIII SMPN 2 Banjarangkan. Dalam penelitiannya dinyatakan bahwa Pembelajaran Kooperatif Numbered Head Together dapat meningkatkan hasil belajar pembelajaran matematika di kelas VIII SMPN 2 Banjarangkan. Kajian yang dilakukan oleh Supena relevan dengan penelitian yang akan dilaksanakan oleh peneliti, sebab penelitian yang dilakukan oleh Supena menggunakan model pembelajaran yang sama dengan penelitian yang akan dilaksanakan oleh peneliti. Sehingga penelitian yang dilakukan oleh Supena dapat dijadikan bahan pertimbangan dan bahan refleksi dalam penelitian yang akan dilaksanakan oleh peneliti.

Uji hipotesis kedua yaitu untuk mengetahui perbedaan hasil belajar geometri antara siswa yang mengkuti model pembelajaran NHT dengan siswa yang mengikuti model pembelajaran konvensional setelah dikendalikan kovariabel kemampuan disajikan pada tabel 3 .

Tabel 3. Rangkuman Hasil Analisis Hasil Belajar Geometri dan Kemampuan Spasial Siswa

\section{Tests of Between-Subjects Effects}

Dependent Variable:X1X2

\begin{tabular}{lccccc}
\hline Source & Type III Sum of Squares & Df & Mean Square & $F$ & Sig. \\
\hline $\begin{array}{l}\text { Corrected } \\
\text { Model }\end{array}$ & $6198.958^{\mathrm{a}}$ & 3 & 2066.319 & 22.996 & .000 \\
Intercept & 7300.677 & 1 & 7300.677 & 81.250 & .000 \\
Y1Y2 & 3721.729 & 1 & 3721.729 & 41.419 & .000 \\
GRUP & 2189.232 & 2 & 1094.616 & 12.182 & .000 \\
Error & 7008.663 & 78 & 89.855 & & \\
Total & 306012.500 & 82 & & & \\
Corrected & 13207.622 & 81 & & & \\
Total & & & & &
\end{tabular}

a. R Squared $=.469$ (Adjusted R Squared $=.449$ ) 
Berdasarkan data yang tersedia di atas tampak bahwa $F_{\text {hitung }}=12,182>F_{\text {tabel }}=4,00$ nilai signifikansi lebih kecil daripada 0,05 yaitu sebesar 0,000 . Hal ini berarti hipotesis nol $(\mathrm{H} 0)$ di tolak dan hipotesis $1(\mathrm{H} 1)$ yang menyatakan bahwa "setelah kovariabel kemampuan spasial dikendalikan, terdapat perbedaan hasil belajar geometri antara siswa yang mengkuti model pembelajaran NHT dengan siswa yang mengikuti model pembelajaran konvensional", diterima.

Setelah kovariabel kemampuan spasial dikendalikan, terdapat perbedaan hasil belajar geometri antara siswa yang mengikuti model pembelajaran NHT dengan siswa yang mengikuti model pembelajaran konvensional. Gardner menyatakan bahwa kecerdasan orisinal (bakat) setiap individu itu berbeda-beda, yang dikelompokkan ke dalam jenis kecerdasan: linguistik, logis-matematis, visual spasial, musikal, kinestetik tubuh, interpersonal, intrapersonal, naturalis, dan eksistensi. Terkait dengan salah satu kemampuan majemuk, kemampuan spasial menurut Piaget dan Inhelder (Tambunan, 2006) adalah konsep abstrak yang di dalamnya meliputi hubungan spasial (kemampuan untuk mengamati hubungan posisi objek dalam ruang), kerangka acuan (tanda yang dipakai sebagai patokan untuk menentukan posisi objek dalam ruang), hubungan proyektif (kemampuan untuk melihat objek dan berbagai sudut pandang), konservasi jarak (kemampuan untuk memperkirakan jarak antara dua titik), representasi spasial (kemampuan untuk mempresentasikan hubungan spasial dengan memanipulasi secara kognitif), rotasi mental (membayangkan perputaran objek dalam ruang). Kemampuan spasial yang merupakan aspek dari kognisi berkembang sejalan dengan perkembangan kognitif yaitu konsep spasial pada tahapan sensori-motor, konsep spasial pada tahapan pra-operasional, konsep spasial pada tahapan konkret-operasional dan konsep spasial pada tahapan formal-operasional. Selama dalam penelitian ini, siswa yang mengikuti pembelajaran dengan model pembelajaran NHT dan model pembelajaran konvensional diberikan tes kemampuan spasial. dalam tes tersebut memang terbukti bahwa siswa yang mengikuti model pembelajaran NHT memiliki rata-rata yang lebih tinggi. Ini juga bukti bahwa kemampuan spasial siswa memang memberikan kontribusi positif kepada pembelajran. Namun dalam penelitian ini, yang menjadi faktor tingginya hasil belajar geometri siswa adalah model pembelajaran yang diterapkan guru, yaitu model pembelajaran NHT.

Kemampuan spasial dalam penelitian ini memberikan kontribusi positif terhadap hasil belajar siswa, walaupun tetap dipengaruhi oleh faktor-faktor yang lainnya seperti keadaan siswa saat pelaksanaan tes dan model pembelajaran yang digunakan guru. Temuan ini juga didukung oleh penelitian Turgut dan Yilmaz tahun 2012 yang berjudul berjudul "Relationships Among Preservice Primary Mathematics Teachers' Gender, Academic Success And Spatial Ability" yang termuat dalam International Journal of Instruction July 2012 Vol.5, No.2. Variabel dalam penelitian tersebut adalah kemampuan spasial, jenis kelamin dan prestasi matematika. Data dianalisis dengan statistik deskriptif menggunakan To Mann-Whitney $U$ test dan Pearson Product Moment Correlation Coefficient berbantuan SPSS 13.0 program. Hasil penelitian menunjukkan terdapat hubungan antara jenis kelamin dan kemampuan spasial terhadap prestasi matematika. Dalam penelitian mereka, disimpulkan bahwa kemampuan spasial memiliki hubungan positif terhadap prestasi matematika.

Jadi, dapat disimpulkan bahwa model pembelajaran NHT lebih unggul daripada model pembelajaran konvensional yang diterapkan pada materi geometri. Ditinjau dari kemampuan spasial siswa, ternyata kemampuan spasial mempunyai pengaruh positif terhadap hasil belajar geometri siswa.

\section{Simpulan dan Saran}

Berdasarkan hasil pengujian hipotesis dan pembahasan, maka dapat ditarik simpulan sebagai berikut. Pertama, terdapat perbedaan hasil belajar geometri antara siswa yang mengikuti model pembelajaran NHT dengan siswa yang mengikuti model pembelajaran konvensional. Hasil belajar geometri siswa yang mengikuti model pembelajaran NHT lebih 
tinggi dari pada hasil belajar siswa yang mengikuti model pembelajaran konvensional. Kualifikasi hasil belajar geometri siswa yang mengikuti model pembelajaran NHT berada pada katagori tinggi, sedangkan hasil belajar siswa yang mengikuti model pembelajaran konvensional berapada pada katagori sedang.Kedua, terdapat perbedaan hasil belajar geometri antara siswa yang mengikuti model pembelajaran NHT dengan siswa yang mengikuti model pembelajaran konvensional setelah kovariabel kemampuan spasial dikendalikan. Ketiga, terdapat kontribusi kemampuan spasial terhadap hasil belajar geometri siswa.

Berdasarkan kesimpulan di atas, beberapa saran yang diajukan adalah sebagai berikut. Bagi guru sekolah dasar diharapkan mencoba menerapkan model pembelajaran NHT dalam pembelajaran geometri. Hal ini perlu dilakukan karena penerapan model pembelajaran NHT dapat meningkatkan hasil belajar matematika siswa. Di samping itu, bila guru ingin mengembangkan kompetensi siswa sebaiknya guru selalu mencoba model-model pembelajaran inovatif lainnya yang memungkinkan dapat mengembangkan kompetensi yang diinginkan. Dalam pembelajaran hendaknya siswa dipandang sebagai subyek yang aktif untuk mencari dan menemukan pengetahuan. Guru perlu lebih kreatif dalam merancang pembelajaran yang memberikan kesempatan kepada siswa untuk menemukan kembali pengetahuan. Hal ini dapat dilakukan melalui diskusi kelompok dan menyelesaikan permasalahan dalam kelompok. Jika siswa menemukan sendiri pengetahuan maka siswa akan lebih memahami apa yang dipelajari. Dengan demikian, pengetahuan yang dimiliki akan melekat lebih kuat dan menjadi pengetahuan awal yang kuat untuk mempelajari pengetahuan baru. Siswa menjadi terbiasa berdiskusi dan tidak sulit mengorganisasikan mereka ke dalam kelompok belajar. Bagi peneliti lain yang ingin mendalami penerapan model pembelajaran NHT diharapkan dapat melakukan penelitian yang lebih memadai. Misalnya penelitian tentang berbagai kendala yang terjadi dalam penelitian ini yang menyebabkan hasil belajar belum optimal

\section{Daftar Pustaka}

Ade. 2009. Model Pembelajaran Kooperatif (Cooperative Learning). Tersedia pada http://adelluckyy.student.fkip.uns.ac.id/k-u-I-i-a-h/s-b-m/model-pembelajarankooperatif/(diakses tanggal 10 April 2012).

Candiasa, I Md. 2010. Statistik Multivariat Disertai Aplikasi dengan SPSS. Singaraja: Unit Penerbitan Universitas Pendidikan Ganesha.

Depdiknas. 2004. Kurikulum Pendidikan Dasar. Jakarta: Depdiknas.

Hasan, I. "Buku Pedoman Pembelajan Geometri". Tersedia pada ttp://idrisharta.blogspot.com/2011/04/buku-pedoman-pembelajaran-geometri.html (diakses tanggal 11 Oktober 2012).

Riyanto, Y. 2010. Paradigma Baru Pembelajaran: Sebagai Refrensi bagi Pendidik dalam Implementasi Pembelajaran yang Efektif dan Berkualitas. Surabaya: Kencana Prenada Media.

Sherman, J.A. 1980. Mathematics, Spatial Visualization, and Related Factors: Changes in Girl and Boys grade 8-11. Journal of Educational Psychology, 72, halaman: 476482.

Smith, P.K. 1980. Spatial Ability. London: University of London Press

Suarjana, I M. 2001. Buku Ajar Pendidikan Matematika I. Singaraja: IKIP Singaraja.

Supena, I W. 2010. Pengaruh Model Pembelajaran Kooperatif Numbered Head Together terhadap hasil belajar IPS ditinjau dari motivasi belajar peserta didik kelas VIII 
SMPN 2 Banjarangkan. Tesis (tidak diterbitkan). Pendidikan Dasar Pasca Sarjana Undiksha.

Tambunan, S.M. 2006. Hubungan antara Kemampuan Spasial dengan Prestasi Belajar Matematika. Termuat pada jurnal Makara, Sosial Humaniora, Vol. 10, No. 1, Juni 2006. Jakarta: Universitas Indonesia.

Tim Redaksi Kompas. 2011. "Indeks Pendidikan Indonesia Menurun". Tersedia pada http://edukasi.kompas.com/read/2011/03/02/18555569/Indeks.Pendidikan.Indonesia .Menurun (diakses tanggal 4 april 2012).

Trianto. 2009. Mendesain Model Pembelajaran Inovatif-Progresif. Surabaya: Prenada Media Group.

Turgut, M dan Yilmaz, S. 2012. Relationships Among Preservice Primary Mathematics Teachers' Gender, Academic Success and Spatial Ability. International Journal of Instruction July 2012 Vol.5, No.2. Turkey. 